\title{
Guaman Poma de Ayala's "New Chronicle and Good Government" A testimony on the health of the Indigenous populations in XVIth century Peru
}

\author{
Axel M. Klohn and Philippe Chastonay
}

\section{Introduction}

$\mathrm{F}$ elipe Guaman Poma de Ayala's illustrated autograph manuscript of nearly 1200 pages: Nueva corónica y buen gobierno (New Chronicle and Good Government), probably written between 1600 and 1615, has particular importance as a rich, in-depth account of early colonialism, seen in an indigenous perspective. The book is attested at the Royal Library of Denmark for more than two centuries ${ }^{1}$. It is available online as a searchable digital edition ${ }^{2}$. Guaman Poma's work, addressed to King Philip III of Spain, was also explicitly intended for the hierarchy of the state and the church ${ }^{3}$ and for a more general public, both Spanish and native ${ }^{4}$. Some critical messages are reserved to Quechua language speakers ${ }^{5}$.

A full-blooded native, Guaman Poma descended from members of an ethnic community, the mitmaqkuna, sent with special privileges by the Inka to settle a newly conquered area ${ }^{6}$. His family, including the priest Martin de Ayala, his halfbrother and instructor, appears to have had a special linkage with the hospital of Huamanga $^{7}$ (today: Ayacucho). This situation, as well as the proximity of mercury

1. Rolena Adorno, Guaman Poma and His Illustrated Chronicle from Colonial Peru: From a Century of Scholarship to a New Era of Reading (Copenhague, 2001)

2. Felipe Guaman Poma de Ayala, El primer nueva corónica y buen gobierno. No. GKS 232, 4. (Copenhague 1615/1616). Available at: http://www.kb.dk/permalink/2006/poma/ info/en/frontpage.htm

3. Felipe Guaman Poma de Ayala, El primer nueva corónica y buen gobierno. pp. 715-716.

4. Felipe Guaman Poma de Ayala, El primer nueva corónica y buen gobierno. p. 1.

5. Rolena Adorno, Guaman Poma: Writing and Resistance in Colonial Peru (Austin, 2000), p. 27.

6. Rolena Adorno, Guaman Poma and His Illustrated Chronicle from Colonial Peru: From a Century of Scholarship to a New Era of Reading. p. 27.

7. Felipe Guaman Poma de Ayala, El primer nueva corónica y buen gobierno. pp. 15-20. 
mines in the region, might explain Guaman Poma's particular attention to the "azogados", the miners poisoned by mercury.

Guaman Poma served the colonial authorities in various activities, notably as a transcultural communicator, an assistant to surveyors of the state of the Church and the Colony, "as a translator, conversing, asking questions to the Spanish poor, the Indian poor, and the black poor" ${ }^{\prime \prime}$. He presents the greater part of his work under the form of the report of a visita general, an overall survey carried out by himself ${ }^{9,10}$.

Regarding his activity as a graphic artist, his hand has been recognized in drawings illustrating a book by the Mercedarian friar Martin de Murúa, dated $1590^{11}$. Guaman Poma's life and views took a radical turn after a traumatic event in December 1600. He lost a protracted legal battle for the control of ancestral lands, was denied dignity and entitlements, and sentenced to public flogging and exile. Guaman Poma then widened his quest for rights - both personal and collective exposing the regime's injustice and excesses, and appealing to the King (of Spain) as a last resort ${ }^{12}$. In his extensive, complex and multi-faceted work, we focus on his observations directly related to health of the population.

\section{Guaman Poma's text}

\section{The extinction of the Andean rural population as a cause of concern and a warning}

Guaman Poma's work is presented as an imaginary dialogue with the King ${ }^{13}$, where he assumes the role of a knowledgeable counsellor. The extinction of the indigenous population is a major cause of concern, stated in the warning: "Holy Catholic Majesty, I say that this kingdom sees the end of the Indians, there will not be any more of them" ${ }^{14}$. The situation is so severe that "where there was a thousand

8. Felipe Guaman Poma de Ayala, El primer nueva corónica y buen gobierno. p. 715.

9. Rolena Adorno, Guaman Poma: Writing and Resistance in Colonial Peru. p. liiii.

10. Felipe Guaman Poma de Ayala, El primer nueva corónica y buen gobierno. pp. 455459.

11. Rolena Adorno, Ivan Boserup, Guaman Poma and the manuscripts of fray Martin de Murúa. Prolegomena to a critical edition of the "Historia del Perú". Fund og Forskning 44 (2005).

12. Rolena Adorno, La génesis de la Nueva crónica y buen gobierno de Felipe Guaman Poma de Ayala. Taller de Letras (Santiago de Chile, 1995), p. 32.

13. Felipe Guaman Poma de Ayala, El primer nueva corónica y buen gobierno. pp. $974-$ 999.

14. Felipe Guaman Poma de Ayala, El primer nueva corónica y buen gobierno. p. 982. 
souls, less than a hundred are left, and so old that they cannot multiply anymore" ${ }^{15}$. "Where there were once a hundred Indian tributaries counted in the general survey, less than ten are to be found today"16. More dramatic examples follow: "In Uchuc Marca there used to be twelve thousand soldiers, and in Uruysa eight thousand. In one or the other of these places there aren't even fifteen tributary soldiers left" ${ }^{17}$. Dire economic consequences are predicted: "the land will be lost, the whole kingdom will remain solitary and deserted, and the King will be impoverished" ${ }^{18}$. The Andean population is depicted as a key asset at the service of the King: "there will be no Indian in this kingdom by which your royal crown and the defence of our holy Catholic faith might be served. Because without the Indians, your Majesty is worth nothing. Because one must remember that Castile is Castile because of the Indians" ${ }^{19}$ (translation by Rolena Adorno ${ }^{20}$ ). Threats to the ability to maintain production and income, such as a decline in the labor force, were prone to attract preferential attention by the Spanish authorities ${ }^{21}$.

\section{The causes of depopulation in the villages according to Guaman Poma}

All along his book, Guaman Poma conveys images of diffuse social disintegration and disorganization. The ancient order is broken, but the new colonial order is detailed as false, corrupt, unjust and ruled by greed and violence. The world is "upside down"22 at all levels, and depopulation is the result. Sexual colonization and sexual violence are forefront themes in Guaman Poma's work ${ }^{23}$. They are indeed quoted among the causes of demographic decline of the indigenous population: "...They do not multiply because the best among the women and maidens are taken by priests, corregidores, encomenderos and their butlers, lieutenants and officers" ${ }^{\prime 24}$. Several of Guaman Poma's illustrations show native women brutalized by white

15. Felipe Guaman Poma de Ayala, El primer nueva corónica y buen gobierno. p. 983.

16. Felipe Guaman Poma de Ayala, El primer nueva corónica y buen gobierno. p. 945.

17. Felipe Guaman Poma de Ayala, El primer nueva corónica y buen gobierno. p. 985.

18. Felipe Guaman Poma de Ayala, El primer nueva corónica y buen gobierno. p. 448.

19. Felipe Guaman Poma de Ayala, El primer nueva corónica y buen gobierno. p. 982.

20. Rolena Adorno, Guaman Poma: Writing and Resistance in Colonial Peru, p. 24.

21. Noble David Cook, Demographic Collapse, Indian Peru, 1520-1620 (Cambridge, 1981), p. 208.

22. Felipe Guaman Poma de Ayala, El primer nueva corónica y buen gobierno. pp. 222, 411, 450, 618, 776, 1136, 1138.

23. Felipe Guaman Poma de Ayala, El primer nueva corónica y buen gobierno. pp. 448, 504, $507,539,543,567,570,577,579,582,604,708,709,710,869,892,893,920,928,943,945,984$, $1113,1125$.

24. Felipe Guaman Poma de Ayala, El primer nueva corónica y buen gobierno. p. 976. 
men, including priests, and forced to work to produce textiles ${ }^{25}$. Accusations of concubinate are used as pretext to sequester the woman and plunder the aborigine's possessions ${ }^{26}$.

The general situation is a cause of despair and of mass suicides: "Facing such damage and grievances, they hang themselves like the Changas Indians in Andaguayllas, where there is a small hill full of (dead) Indians. They prefer to die at once rather than see themselves in dire straits" ${ }^{27}$. The offspring stemming from sexual abuse, mestizos, were dispensed from servage and forced work. The privileges of the mestizos tended to further concentrate the burden of forced work on the remaining "indians". The reforms introduced by Viceroy Francisco de Toledo, which included forced relocation and population concentrations, meant a menace by themselves ${ }^{28}$.

Forced work in the mines is associated with high lethality, especially in the mercury mines of Huancavélica where "the poor Indians are subject to many punishments and cruel treatments, and there are many deaths" ${ }^{\prime 29}$, both because of the physical dangers incurred and as an outcome of corruption and bad treatment inflicted to the forced workers: "To begin, they receive great damage from the miners and authorities who get there. They are hanged by the feet and flogged nude... they are forced to work day and night, and they do not receive any pay. If they ever get paid, half of the amount is stolen. They are expelled to the plains where they are left to die. Of eleven Indians, only one gets out of there" ${ }^{30}$. Fear of cruel treatment and death in the mines are a cause of flight, deserting the villages: "Because of all these offenses, they go missing from their villages so as to avoid the hell of the mines and suffering pains and torment from the devils. Others flee from the mines, others from the roads, to avoid going to the mines and dying an early death. They prefer death to life, they say that they would prefer to die at once, because if they catch the illness from mercury, they dry up as wood, they get asthma and they cannot live day or night. It goes on in this manner for a year or two, then they die" ${ }^{31}$. Many of the fugitives migrate to the cities. In Lima "I saw quantities of absentee and fugitive Indians working as servants... they dressed like the Spanish... so as to avoid paying the tribute and serving in the mines. You see

25. Felipe Guaman Poma de Ayala, El primer nueva corónica y buen gobierno. pp. 578, 659, 661.

26. Felipe Guaman Poma de Ayala, El primer nueva corónica y buen gobierno. pp. 578, 668, 976.

27. Felipe Guaman Poma de Ayala, El primer nueva corónica y buen gobierno. p. 977.

28. Felipe Guaman Poma de Ayala, El primer nueva corónica y buen gobierno. p. 448.

29. Felipe Guaman Poma de Ayala, El primer nueva corónica y buen gobierno. p. 530.

30. Felipe Guaman Poma de Ayala, El primer nueva corónica y buen gobierno. p. 982.

31. Felipe Guaman Poma de Ayala, El primer nueva corónica y buen gobierno. p. 531. 
here the world upside down. As they see those absentee Indians, others leave their villages and no one is left to pay the tributes and to serve in the mines"32.

Guaman Poma also reports on the disruption caused by the policies of forced relocation and concentration ("reduction") of the indigenous populations carried out by Viceroy Francisco de Toledo with the aim of increasing $\operatorname{control}^{33}$ and streamlining the collection of taxes and services: "He ordered the reduction and relocation of the Indians, some in good places, some in bad places, according to chance. Because of this, the Indians were uprooted from their homes, having their fields so far away" ${ }^{34}$. Urban areas carry risks of their own: death by "pestilence" is associated with cities and villages ${ }^{35}$. Elsewhere, Guaman Poma mentions epidemics as causes of mortality starting in early contact years: "There were huge pestilences of measles and smallpox in times of the Inca Huayna Capac. Many people died, including the Inca himself. It is said that he went hiding in a cavern, for fear of the pestilence, and there he died"36. Later on, in times of Viceroy Fernando de Torres y Portugal, "There was a big earthquake that brought down houses and walls. And there was pestilence of measles, smallpox and typhus, causing many deaths in this kingdom, as well as a dire lack of food. And there were many poor, orphans and widows, and many blind" ${ }^{\text {"36 }}$. The effects of "pestilence" were well known by Guaman Poma, but he does not enlist them among the main concerns about depopulation.

\section{Guaman Poma's reform proposals}

Rolena Adorno noted that the final report by Viceroy Juan de Mendoza y Luna ${ }^{37}$ and Guaman Poma's book (both are dated 1615) share many recommendations for reform and criticisms of the abuses committed at the expense of the Andean natives. Guaman Poma's proposals for administrative, civil and ecclesiastic reform are distributed throughout his manuscript. They have been identified as fluctuating between "Toledan" (reformist, authoritarian) and "Lascasian" (autonomy and selfgovernment) poles ${ }^{38}$. The latter deal with the restitution of power to the traditional indigenous chiefs ${ }^{39}$, yet excluding alcoholics as well as addicts to gaming or to

32. Felipe Guaman Poma de Ayala, El primer nueva corónica y buen gobierno. p. 1138.

33. Juan López de Velasco, Geografía y descripción universal de las Indias (Madrid, 1894), p. 35.

34. Felipe Guaman Poma de Ayala, El primer nueva corónica y buen gobierno. p. 447.

35. Felipe Guaman Poma de Ayala, El primer nueva corónica y buen gobierno. p. 1073.

36. Felipe Guaman Poma de Ayala, El primer nueva corónica y buen gobierno. p. 288.

37. Juan de Mendoza y Luna, Luz de materias de Indias del Marques de Montes claros (Lima $1615)$.

38. Rolena Adorno, La génesis de la Nueva crónica y buen gobierno de Felipe Guaman Poma de Ayala. Taller de Letras (Santiago de Chile, 1995).

39. Felipe Guaman Poma de Ayala, El primer nueva corónica y buen gobierno. pp. 945, 987. 
coca $^{40}$. These chiefs should be fluent in both Spanish and Quechua, and, "if possible, they should know Latin, to read, to write, to count, and to make petitions and questionnaires to defend their Indian subjects" ${ }^{\prime 1}$.

Guaman Poma's core points are sharp and clear: The existing laws should be applied, the Spanish should behave, and the natives left in peace: "That the priests, friars, encomenderos (trustees of christianization), corregidores (civil authorities) and other Spaniards, as well as the Indigenous chieftains, should live as Christians and according to your Majesty's rule, without infringing it, and leave them (the Indians) the usage of their wives and properties, and leave alone their maidens" ${ }^{\prime 2}$. "All the Spanish should live as Christians, should try to marry ladies within their own quality, and leave alone the poor Indians to multiply, and leave alone their possessions of lands and houses. What has been taken by force should be returned to them, and they should be compensated for the improper use" ${ }^{43}$. The judges should not set obstacles to justice: "and if the judge refuses to execute the sentence, he should be condemned to the same penalty" ${ }^{\text {" } 33}$.

Practical proposals further develop out of those main points: The encomenderos $^{44}$, the Spanish and the mestizos, all of the non-Indians ${ }^{45}$ should be barred from entering the villages of the Indians. Guaman Poma describes this measure among the (unapplied) rulings of Viceroy Francisco de Toledo. So is the recommendation "that officers, priests and encomenderos should live on their allocated salaries" 46 . "The administrators of Indian possessions, of Church possessions and of hospitals should receive a salary and be brought to book every six months" ${ }^{\prime 7}$.

Priests, trustees and other Spanish should stop administering justice and this task should be reserved to trained professionals. Infringers should be punished and exiled $^{48}$. Alimony collected by priests during the masses should be enough to sustain them and they should be barred from collecting taxes and tributes ${ }^{49}$. They should keep an account of alimonies and donations, and the balance should be employed in paying for masses ${ }^{50}$. Priests should be held to put down a deposit before going to

40. Felipe Guaman Poma de Ayala, El primer nueva corónica y buen gobierno. pp. 785, 945, 987.

41. Felipe Guaman Poma de Ayala, El primer nueva corónica y buen gobierno. p. 785.

42. Felipe Guaman Poma de Ayala, El primer nueva corónica y buen gobierno. p. 977.

43. Felipe Guaman Poma de Ayala, El primer nueva corónica y buen gobierno. p. 984.

44. Felipe Guaman Poma de Ayala, El primer nueva corónica y buen gobierno. p. 987.

45. Felipe Guaman Poma de Ayala, El primer nueva corónica y buen gobierno. pp. 448, $1127,1128$.

46. Felipe Guaman Poma de Ayala, El primer nueva corónica y buen gobierno. p. 449.

47. Felipe Guaman Poma de Ayala, El primer nueva corónica y buen gobierno. p. 985.

48. Felipe Guaman Poma de Ayala, El primer nueva corónica y buen gobierno. p. 985.

49. Felipe Guaman Poma de Ayala, El primer nueva corónica y buen gobierno. p. 978.

50. Felipe Guaman Poma de Ayala, El primer nueva corónica y buen gobierno. p. 635. 
any indigenous village, even for a single day. If they commit any abuses, they should be punished and not simply rotated among parishes ${ }^{48}$. All of the children and youth, boys and girls, should be taught to read and write, and the teachers should be paid with the church's revenues ${ }^{51}$. There should be schools in every village, small or large ${ }^{52}$. Each village should have its scribe, acting as book-keeper and authorized to bear witness ${ }^{53}$.

Some of Guaman Poma's proposals directly address health and health care, especially in the mines: "Your Majesty should mandate and pay an Indian, or a black, or a Spanish, someone who knows how to treat and cure the mercury intoxications, then the Indians will multiply and will not fear work [in the mines]" ${ }^{54}$ " "Children and the young should not enter any mine of mercury, silver or gold, nor should they work at the smelter ovens" $"$. A work schedule and rotations should be adapted so as to reduce exposition times and lower the risk of illness ${ }^{55}$.

\section{Discussion}

\section{Is emphasis on the sole role of epidemies justified? Fresh evidence for the destructive power of social disruption}

There is a generally accepted evidence of a XVIth century demographical collapse in the major societies of the Americas. Nathan Wachtel estimated the 1530-1580 population reduction of Peru at $80 \%$ of a pre-contact population of $8-10$ million ${ }^{56}$.

Yet multidisciplinary research is showing "compelling evidence that the arrival of Europeans did not occasion a sudden pandemic of smallpox in the early sixteenth century": populations were variously affected by the new infectious diseases, in an heterogeneous pattern ${ }^{57}$. According to Cook, on the basis of reconstructed population data for Perú, the population decrease was more pronounced in the coastal areas and in the lowlands ( -2.4 to -3.5 percent yearly). High-altitude areas experienced a slower population loss ( -1.4 percent yearly). This author attributes the differences observed to epidemic diseases. Overall "the native Andean resident

51. Felipe Guaman Poma de Ayala, El primer nueva corónica y buen gobierno. p. 685.

52. Felipe Guaman Poma de Ayala, El primer nueva corónica y buen gobierno. p. 686.

53. Felipe Guaman Poma de Ayala, El primer nueva corónica y buen gobierno. p. 829.

54. Felipe Guaman Poma de Ayala, El primer nueva corónica y buen gobierno. p. 982.

55. Felipe Guaman Poma de Ayala, El primer nueva corónica y buen gobierno. p. 988.

56. Nathan Wachtel, La vision des vaincus. Les Indiens du Pérou devant la Conquête espagnole 1530-1570 (Paris, 1971).

57. Clark Spencer Larsen, "In the wake of Columbus: native population biology in the postcontact Americas". Yearb Phys Anthropol 37 (1994), pp. 109-154. 
risked less mortality living near and, in fact, perhaps working as a mitayo at Huancavélica than did the Indian resident of Piura, Trujillo, Canamá, or elsewhere on the Peruvian coast or in the northeastern frontier of the Amazon basin" ${ }^{\text {58 }}$. In the central highlands, the rapid depopulation is attributed to "both deaths and migration to avoid mita service. By moving to another corregimiento, Indians, as forasteros (strangers) were exempt from mita service" ${ }^{\text {"9 }}$.

According to this view, infectious diseases would be taking a heavier toll than even the deadliest of the mines. Yet the analysis is not quite satisfying. There is more to Indian's mortality than the simple spread of imported infectious diseases: Bioarcheology research has been showing patterns of post-contact increases in biological stress indicators throughout the Americas. A sustained post-contact decline in mean adult stature has also been observed in Middle and South America, sustained well into the XXth century ${ }^{60}$. In Perú, Klaus and Tam have recently evidenced significant post-contact increases of porotic hyperostosis and periosteal inflammation, both systemic biological stress indicators, as well as sub-adult growth faltering and depressed female fertility ${ }^{61}$. What was the source of the observed biological stress? Upon conquest, and with the aim to maximize the extraction of revenue and work, the Spanish embarked in a vast enterprise that transformed every aspect of the environment and life of the indigenous populations, radically altering their risk and vulnerability profiles. Just as in the Lambayeque valley complex, previously dispersed uphill settlements were concentrated down in marginal environments, with large increases in population density. Work, water supply and the best soils were diverted to plantation crops for the colonialists. The resulting weakening of the native populations, increased population density, deep transformations of the environment and of social organization, all concurred to convert colonial reductions into "disease reactors" ${ }^{\text {" }}$.

In the highlands, mining operations had effects not unlike plantation crops in the lowlands. The mercury mines of Huancavélica were known as "the mines of death". According to a rough estimation by Kendall W. Brown, by 1600 about two thirds of the miners died of mercury intoxication. The death toll in the Huancavélica mines, with its forced labour, appears to have been significantly heavier than in the Old World mercury mines of Almadén, where mostly free miners were employed. Incompetence, uncertain tenure and racial prejudice could explain this large difference in mortality: the indigenous workforce was treated as

58. Noble David Cook, Demographic Collapse, Indian Peru, 1520-1620 (Cambridge, 1981), p. 208.

59. Noble David Cook, Demographic Collapse, Indian Peru, 1520-1620, p. 210.

60. Barry Bogin, Ryan Keep, "Eight thousand years of economic and political history in Latin America revealed by anthropometry", Ann Hum Biol. 26 (1999), pp. 333-351.

61. Haagen D. Klaus, Manuel E. Tam, "Contact in the Andes: Bioarchaeology of systemic stress in colonial Mórrope, Peru”. Am J Phys Anthropol 138 (2009), pp. 356-368. 
an expendable resource. Several official reports acknowledged the gravity of the situation in Huancavélica; a senior officer qualified the mine as "a public slaughterhouse", and the closure of the mine was considered. However, short-term economic advantage prevailed over any other concern, since mercury was needed in the process to extract precious metals, and the mines, however lethal, were kept in function $^{62}$.

\section{The causes of the extinction of the native populations according to other contemporary authors}

Contemporary scholars stress the importance of contextual factors, social disruption and mistreatment in the demographic collapse of the native populations. This was already well known to XVIth century chroniclers: much data on the colonies was available thanks to systematic surveys ${ }^{63}$, as well as an official policy promoting an open flow of information ${ }^{64}$.

According to Bartolomé de Las Casas, who had personal experience of colonial wars in the Caribbean islands, war and ruthless exploitation were the two main causes of extinction of the indigenous populations:

There are two main ways in which those who have travelled to this part of the world pretending to be Christians have uprooted these pitiful nations and wiped them from the face of the earth. First, they have waged war on them: unjust, cruel, bloody and tyrannical wars. Second, after having murdered anyone and everyone who might aspire or think about liberty, or about escaping the torments they suffer - including the native leaders and the adult males (given that the Spaniards normally spare only women and children), by oppressing them under the harshest, most horrible and brutal servitude ever suffered by men or animals alike... The only reason for which Christians have destroyed so many souls, in such infinite numbers, has been to get hold of the gold, and to get rich in a very short time...65

Those points are further developed and refined by de Las Casas in his later works. Exploitation may not always be the immediate cause of death, but a

62. Kendall W. Brown, "Workers' Health and Colonial Mercury Mining at Huancavélica, Peru”. The Americas, 57 (2001), pp. 467-496.

63. Howard Francis Cline, "The Relaciones Geograficas of the Spanish Indies, 15771586", Hispanic Am Hist Review, 44 (1964), pp. 341-374.

64. Lewis Hanke, "Free Speech in Sixteenth-Century Spanish America", Hispanic Am Hist Review, 26 (1946), pp. 135-149.

65. Bartolomé de las Casas, Très brève relation de la destruction des Indes (Paris, 1996), p. 52. 
contributing factor. In "History of the Indies", he reports on a devastating epidemic of smallpox spreading in the Caribbean in 1518-19:

A terrible plague came, by which almost all of the Indians died, and only a small number remained in life. This was smallpox, brought by someone from Castile.

But contextual factors related to exploitation contributed to increase vulnerability:

The condition of frailty and weakness due to lack of food, the nudity, sleeping on the ground, the excess of work imposed on them, and, on the side of those who used them, utter lack of concern for their health and conservation. 66

Their deaths result from negligence and greed:

The intention was not outright to kill them, but to use them as if they were animals, putting the physical and spiritual health of the Indians after their own interests, greed and earnings. ${ }^{67}$

The economic benefits extracted by forced work could indeed explain the colonialist's fierce hostility against any attempt at instating protection measures for the indigenous population, such as the "New Laws" promoted by de Las Casas ${ }^{68}$ and made effective in 1542. According to Francisco López de Gómara:

Perú was the place where they [the colonialists] rebelled more strongly against them, as [the laws] were brought from village to village. In many of those, the bells were rung as tocsin, and people howled with rage while reading them. Some would sadden, fearing execution. Others pestered, and all cursed Fray Bartolomé de Las Casas, who had impulsed them. Men would stop eating, women and children cried, the Indians became arrogant and the cause of much concern. ${ }^{69}$

Ultimately, attempts as enforcing the "New Laws" were effectively opposed by local colonial interests. This conflict was in fact a main cause of the civil war in Peru from 1542 to 1548. As a consequence, enforcement of most of the laws destined to the protection of the Indians was postponed sine die and mistreatment continued.

Some XVIth century scholars, such as Juan López de Velasco, official chronicler and cosmographist to the Council of Indies and to King Philip II, made remarkable

66. Bartolomé de las Casas, Historia de las Indias V(Madrid, 1875), p. 23.

67. Bartolomé de las Casas, Histoire des Indes III (Paris, 2002), p. 166.

68. Matthias Morys, "Fray Bartolomé de Las Casas y su influencia sobre las Leyes nuevas de Indias de 1542", Studium 43 (2003), pp. 117-146.

69. Francisco López de Gómara, Historia general de las Indias (Madrid, 1922), p. 96. 
uses of "general survey" techniques based on directed questionnaires ${ }^{70}$. About the causes of the disappearance of the indigenous population, this author states:

In all of the discovered lands, at the beginning the natives were many more in numbers than those who have followed. In some provinces, where there were a great many of them, they have gone almost into extinction. At the beginning the causes of their disappearance were wars, because of the many who died in battles and skirmishes. Desperate to see themselves defeated, not willing to submit in peace, others left for the mountains, abandoned their cultures, and died of hunger. Then followed, in the prime years, widespread deaths and diseases never seen in those places, such as the smallpox brought by the Spanish. Later on, in more recent times, many more have disappeared as a result of mistreatment at the hands of the Spanish, excessive work with excessive loads, because at the beginning there were no other pack animals but them, and with the work in the gold and silver mines, pearl fisheries, country haciendas and in the building of edifices... ${ }^{71}$

This text suggests a quite clear picture of multiple causes for the extinction of the indigenous peoples, with forced work among the main factors. Writing about the Kingdom of New Granada (today's Colombia), the same author signals differential mortality among hot (humid tropical) and cold (highland) places: "every day there are less and less Indians in the hot lands, and those from the cold are increasing". The causes, according to him, are also directly related to work:

They say the reason is, the Indians of the cold lands are many and slow, and do not have so much work, while the others must work in the mines. ${ }^{72}$

Fifty years after Guaman Poma's work, Accarette du Biscay witnessed the established practices in the reputedly "milder" Potosí silver mines:

[It is in the interest of the King] that a sufficient number of them [Indians] be available to work in all of the mines. For those ends, the curacas or chiefs of the savages are forced to provide a certain number of workers that must be available at any time, least they (the curacas) pay in silver twice the amount that the absentees would have received if they were present... They are brought to a big enclosed terrain at the foot of the mountain. There, every Monday the corregidor distributes them [the Indians] among the foremen of the mine according to the number of workers they need. Next Saturday, after six days of continued work, the foremen return them to the same place... They count how many of them have died, for curacas to replace the

70. Howard Francis Cline "The Relaciones Geograficas of the Spanish Indies, 1577-1586", Hispanic Am Hist Review 44 (1964), pp. 341-374.

71. Juan López de Velasco, Geografia y descripción universal de las Indias, p. 26.

72. Juan López de Velasco, Geografia y descripción universal de las Indias, p. 359. 
missing numbers, as not a week passes without some deaths, caused by various accidents, such as mine collapses, falling stones and other fortuituous cases, or by diseases. Sometimes they are much incommodated by the wind that blows in the galleries. In some places, the harsh cold of the wind and of the ground is such that, were it not for the coca leaves they chew to warm up and inebriate themselves, it would be intolerable. In other places they suffer from strong sulfurous gases and minerals that dry them up, sometimes to the point that they are prevented from normal breathing. ${ }^{73}$

\section{Conclusions}

Guaman Poma emerges as a most valuable primary source on indigenous health conditions and the problems predominant in late XVIth-early XVIIth century in Central Perú. His observations are consistent with and reinforce the current evidence on the health of the post-contact native populations in this area. All along his book, he exposes double standards and duplicity at all levels of the colonial power structure. If both las Casas and Guaman Poma knew well about the devastation caused by epidemies, it can be argued that they focused on the more directly evitable causes of mortality: those related to mistreatment and misbehaviour by the colonials.

The XVIth century appears as a flash point in the emergence of the modern concepts and practices, from the onset of the colonial "New World" order. The revulsion caused by the "worst genocide ever" ${ }^{\text {" }}$ would in turn fuel the elaboration, heeded by Bartolomé de Las Casas and Francisco de Vitoria, of the fundaments of a doctrine of universal rights (Las Casas would however disagree on the latter's troubling concepts about a "just war"). But the resulting laws, a compromise tailored to protect the indigenous populations, were never applied. Guaman Poma's work would lay forgotten in shelves for more than 300 years, and Las Casas texts were barred from publication after his death: by 1600, the XVIth century "free speech" practice was already a thing of the past ${ }^{75}$. Colonial order appears, according to the terms of Las Casas, as "a tyranny by fact, not by law" predominance of de facto power structures, and a persistent disregard towards the laws emanating from the central authority. This mode of organization of the conquistadors and their successors has its roots in a primitive, pre-contractual, early

73. Accarette du Biscay, Viajes al Río de la Plata y a Potosí (1657-1660) (Doral, FL, 2008)

74. Tzvetan Todorov, La conquête de l'Amérique. La question de l'autre, (Paris, 1982), p. 170.

75. Lewis Hanke, "Free Speech in Sixteenth-Century Spanish America" Hispanic Am Hist Review, 26 (1946), pp. 135-149.

76. Bartolomé de las Casas, Historia de las Indias V(Madrid, 1875), p. 10. 
middle ages feudal custom ${ }^{77}$. It would spread to many more territories as other countries entered the colonial competition. Ultimately, more or less tacit territories "beyond the line", where ordinary laws are suspended and remain unapplied, akin to a permanent "state of exception", would become a key feature of colonialism ${ }^{78}$. In spite of apparent changes, a surprising continuity in de facto political power and institutions has been found in many of those territories ${ }^{79,80}$. Avenues for further research might find fertile ground in the conditions for the post-colonial persistence, decline and re-emergence of spaces of suspended law, as they might still be among the main challenges to the improvement of access to health and the respect of the fundamental rights of indigenous populations. This acquires particular relevance given the worsening discrimination, exploitation, dispossession and racism experienced by the majority of indigenous peoples ${ }^{81}$.

Philippe Chastonay, MD, MPH, president of the scientific committee of the Swiss Society of Public Health.

Axel Max Klohn, MD, MPH, lecturer at the University of Geneva, Institute of Global Health.

77. Ruggiero Romano, Les Conquistadores. Les mécanismes de la conquête coloniale (Paris, 1972), p. 32.

78. Carl Schmitt, Le nomos de la Terre dans le droit des gens du Jus Publicum Europaeum (Paris, 2001), pp. 87-101.

79. Daron Acemoglu, James Robinson, "De Facto Political Power and Institutional Persistence” American Economic Review, 96 (2006), pp. 325-330.

80. Daron Acemoglu, James Robinson, Persistence of Power, Elites and Institutions (Cambridge, 2006).

81. Susana Sawyer, Terence Gomez, Transnational Governmentality and Resource Extraction: Indigenous Peoples, Multinational Corporations, Multinational Institutions and the State (Geneva, 2008). 


\section{References}

Acemoglu, Daron and James Robinson, "De Facto Political Power and Institutional Persistence," American Economic Review 96(2) (2006), 325-330.

Acemoglu, Daron and James Robinson, Persistence of Power, Elites and Institutions. Cambridge, 2006

Adorno, Rolena, "La génesis de la Nueva crónica y buen gobierno de Felipe Guaman Poma de Ayala," Taller de Letras 23 (1995), 9-32.

Adorno, Rolena, Guaman Poma: Writing and Resistance in Colonial Peru. Austin, 2000.

Adorno, Rolena, Guaman Poma and His Illustrated Chronicle from Colonial Peru: From a Century of Scholarship to a New Era of Reading. København, 2001.

Adorno, Rolena and Ivan Boserup, "Guaman Poma and the manuscripts of fray Martin de Murúa. Prolegomena to a critical edition of the Historia del Perú," Fund og Forskning 44 (2005), 107-258.

Biscay, Accarette du, Viajes al Río de la Plata y a Potosi (1657-1660). Doral, 2008.

Bogin, Barry and Ryan Keep, "Eight thousand years of economic and political history in Latin America revealed by anthropometry," Ann Hum Biol 26 (1999), 333-351.

Brown, Kendall W., "Workers' Health and Colonial Mercury Mining at Huancavélica, Peru," The Americas 57(4) (2001), 467-496.

Casas, Bartolomé de las, Très brève relation de la destruction des Indes. Paris, 1996.

Casas, Bartolomé de las, Histoire des Indes III, Paris, 2002.

Casas, Bartolomé de las, Historia de las Indias V, Madrid, 1875.

Cline, Howard Francis "The Relaciones Geograficas of the Spanish Indies, 15771586," Hispanic Am Hist Review 44(3) (1964), 341-374.

Cook, Noble David, Demographic Collapse, Indian Peru, 1520-1620. Cambridge, 1981.

Guaman Poma de Ayala, Felipe, El primer nueva corónica y buen gobierno. København, 1615/1616.

Hanke, Lewis, "Free Speech in Sixteenth-Century Spanish America," Hispanic Am Hist Review 26(2) (1946), 135-149.

Klaus, Haagen D. and Manuel E. Tam, "Contact in the Andes: Bioarchaeology of systemic stress in colonial Mórrope, Peru," Am J Phys Anthropol 138 (2009), 356-368.

Larsen, Clark Spencer, "In the wake of Columbus: native population biology in the postcontact Americas," Yearb Phys Anthropol 37 (1994), 109-154

López de Gómara, Francisco, Historia general de las Indias. Madrid, 1922.

López de Velasco, Juan, Geografía y descripción universal de las Indias. Madrid, 1894. 
Mendoza y Luna, Juan de, Luz de materias de Indias del Marques de Montes claros. Lima, 1615.

Morys, Matthias, "Fray Bartolomé de Las Casas y su influencia sobre las Leyes nuevas de Indias de 1542," Studium 43(1) (2003), 117-146.

Romano, Ruggiero, Les Conquistadores. Les mécanismes de la conquête coloniale. Paris, 1972.

Sawyer, Susana and Terence Gomez, Transnational Governmentality and Resource Extraction: Indigenous Peoples, Multinational Corporations, Multinational Institutions and the State. Geneva, 2008.

Schmitt, Carl, Le nomos de la Terre dans le droit des gens du Jus Publicum Europaeum. Paris, 2001.

Todorov, Tzvetan, La conquête de l'Amérique. La question de l'autre. Paris, 1982.

Wachtel, Nathan, La vision des vaincus. Les Indiens du Pérou devant la Conquête espagnole 1530-1570. Paris, 1971. 